\title{
RAINWATER HARVESTING SYSTEM (MYRAWAS): TOWARDS UPSCALING WATER-CONSERVING PRACTICE AT UNIVERSITY LEVEL
}

\author{
Marlia M. Hanafiah* \\ School of Environmental and Natural Resource Sciences, Faculty of Science and Technology, Universiti Kebangsaan Malaysia, 43600 UKM Bangi, \\ Selangor, Malaysia. \\ *Corresponding author email: mhmarlia@ukm.edu.my
}

This is an open access article distributed under the Creative Commons Attribution License, which permits unrestricted use, distribution, and reproduction in any medium, provided the original work is properly cited.

\section{ARTICLE DETAILS}

\section{Article History:}

Received 12 November 2017 Accepted 12 December 2017 Available online 1 January 2018

\begin{abstract}
With rapid population growth and growing demand on the water supply, rainwater harvesting has been seen as a viable alternative for providing clean water supplies for domestic uses. In accordance with the urgency, the rainwater harvesting system (MyRAWAS) has been designed and installed to supply water for domestic uses at Kolej Ungku Omar residential college, Universiti Kebangsaan Malaysia. Although the quality of rainwater from a rainwater harvesting system can vary depending on environmental conditions, selection and installation of appropriate storage and catchment materials together with the application of post-cistern treatment can significantly improve harvested rainwater and reduce cistern cleaning. The development of rainwater harvesting system, also known as MyRAWAS is one of the important initiatives towards sustainable water management in UKM that is located within the Langat watershed, Selangor.
\end{abstract}

\section{KEYWORDS}

Rainwater harvesting system, water quality, sustainable water resource, MyRAWAS, Malaysia

\section{INTRODUCTION}

The Malaysian government has identified a number of efforts to overcome the issue of water scarcity due to recent climate variability. One of the alternatives identified is rainwater harvesting system. Rainwater harvesting system aims to slow the flow of runoff and as alternative source of water supply that is free and safe to be consumed. A rainwater harvesting system is a method of collecting rainwater from man-made surfaces such as rooftops and constructed surfaces and can be used for various sectors including household, agricultural and commercial. This collection system is feasible and educational way to reduce potable water use. Rainwater harvesting involves the collection and storage of rainwater for re-use for various activities, including the purpose of watering plants, livestock, irrigation for agriculture, for domestic uses (through appropriate water treatment methods) and other daily activities. Rainwater harvesting methods have been introduced and implemented to reduce the amount of water that flows directly on the soil surface during raining times and thus reduce the possibility of flooding [1-2].

Rainwater harvesting plays an important role in promoting sustainable urban water management and it is considered as one of the best alternatives to avoid the issue of water shortage in the long run [3]. Besides supplying water for domestic usage during water crisis, it can also be used to recharge the groundwater, reduce the runoff and water logging during heavy rainfall. Rainwater harvesting system is easy to install, operate, and maintain and it can be used as the back-up source of water for emergencies. Water collected from the roof catchment can be used directly for potable and non-potable purposes such as toilet flushing, laundries and water bathing. Rainwater harvesting system has less negative environmental impacts because the rainwater will be collected using existing structures (i.e., at the building's rooftop). Rainwater is freely available therefore rainwater harvesting system can save money on utility bills, makes efficient use of a rainwater and reduces the demand on the municipal water supply [4]. The only cost incurred is for collection and use of rainwater. The system can also be easily retrofitted to an existing structure as well as relocated to other building. The effectiveness of the rainwater harvesting system as a domestic water supply has been recorded by previous studies. Herrmann and Schmida showed that a potential saving from harvested rainwater was about $30 \%-60 \%$ of potable water demand [5]. According to other studies, rainwater harvesting system in Australia could save $60 \%$ of potable water, while other researchers found that about $12 \%$ - 79\% of potable water in Brazil could be saved by using rainwater harvesting system $[6,7]$.

\section{RAINWATER HARVESTING SYSTEM (MYRAWAS)}

A green initiative has been taken up by a group of researchers at UKM by introducing MyRAWAS. MyRAWAS was installed at the female student flats (K8M and K8K) at Ungku Omar which is one of the residential colleges at UKM. Rainwater was collected from the rooftops of the selected flats at KUO, UKM. The components of rainwater harvesting consist of catchment area, downpipes, gutters, filter, flush, inlet and outlet of the floating-ball valve and storage tank. The roofs, gutters and water tank were cleaned prior to the rainwater collection. Down pipe and flush arrangement were installed to prevent dust and other unwanted materials from reaching the storage tank. Rainwater collected from the rooftop will reach the storage tank through a filtering mechanism using rubble and sand. MyRAWAS consists of three components namely collection tank, treatment tank and storage tank. Storage tank was constructed above ground for rainwater harvesting and equipped with floating-ball valve. The storage tank will be first filled by rainwater and then automatically diverts to fill the treatment tank. The rainwater is treated using a series of filtration using gravel, sand and activated carbon. Rain water that has been through the treatment process is then connected to the storage tank.

This study aims to look at the potential of rainwater harvesting as an alternative source of water supply. MyRAWAS is seen as an eco-friendly prototype to solve the problem of lack of water resources and reliance on existing water resources towards sustainable water management within Langat watershed. Figures 1 and 2 show the logo and the project site of MyRAWAS installation at Ungku Omar Residential College (KUO), UKM, respectively. This engineering schematic blueprint can be used in the problem-based solution and the concept of sustainable practice and green living (Figure 3). 


\section{MyRAWA}

Figure 1: Logo of MyRAWAS

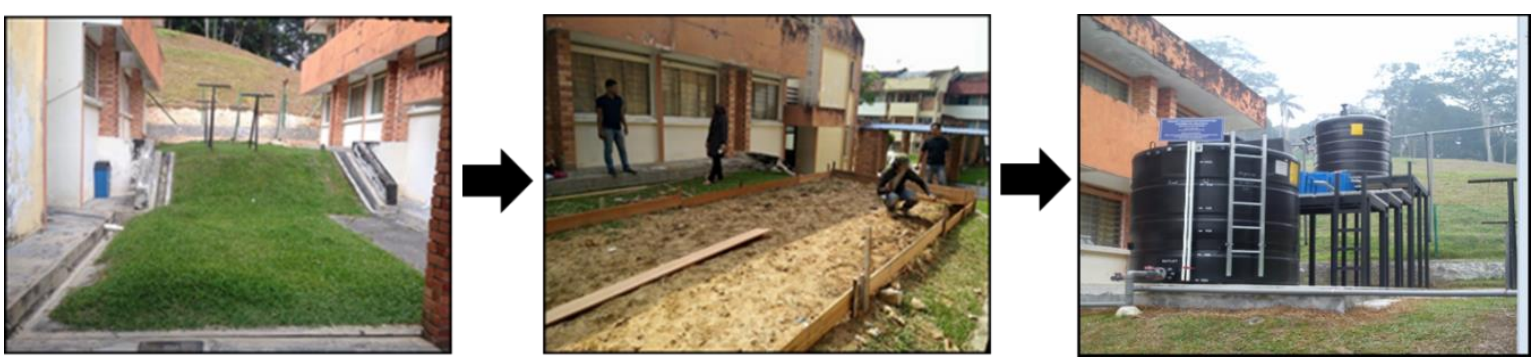

Figure 2: MyRAWAS that has been installed at KUO, UKM

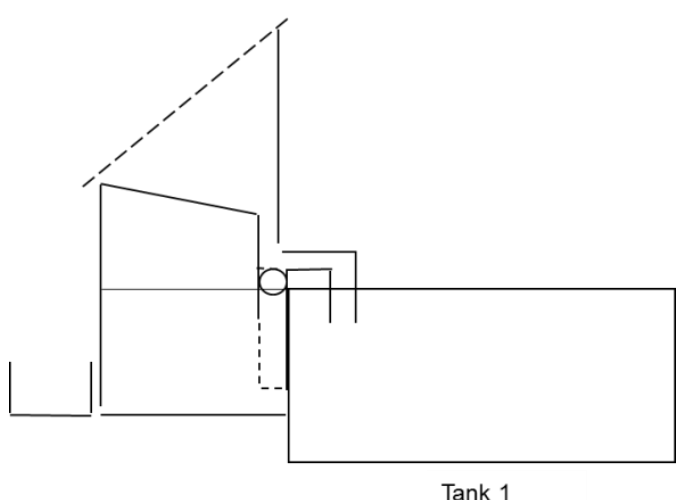

Figure 3: Schematic view of a rainwater harvesting system

The development of this pilot rainwater harvesting system is one of the important initiatives towards sustainable water management in UKM and can solve the water shortage issue in residential colleges in UKM. This initiative creates innovation by incorporating green engineering method on managing integrated sustainable water management which can substitute the conventional method that can negatively impact the environment and public health. Introduction and installation of MyRAWAS can also create potential commercial of small to medium scale of rainwater management particularly for the residential housing area and small to medium size business. Furthermore, the application of rainwater harvesting system can help in achieving LEED Green Building Rating Credit. This research can also give positive impact to the society by promoting a greater awareness of the importance of freshwater as a valuable resource that need to be conserved. New scientific knowledge pertaining to the concept of sustainability and rainwater harvesting system is gained by students and local community through campaigns and courses.

However, the quality of harvested rainwater from roof top depends on both roof top quality and surrounding environmental conditions. The environmental conditions include local climate, air quality, etc. [8]. Previous studies indicated that rainwater quality did not always meet the standards due to improper collection [9-11]. Rainwater harvested from roof usually is not in good quality and requires further treatment before it can be consumed. Therefore, a study on treatment of harvested rainwater should be conducted to make water potable and free from pollutants.

\section{CONCLUSIONS AND WAY FORWARD}

MyRAWAS is an innovation helps to solve the water shortage issue at UKM that have high potential to be patent and commercialize. In addition, this pilot project gives positive impact to the society by promoting a greater awareness of the importance of freshwater as a valuable resource that need to be conserved. New scientific knowledge pertaining to the concept of sustainability and rainwater harvesting system was also gained by students and local community through campaigns and courses. The installation of the rainwater harvesting system can promote significant water saving, thus reduce water bills and demand on university's water supply by using rainwater for flushing toilets, washing clothes, watering the garden and other domestic uses. The financial benefit of MyRAWAS is associated with cost. Therefore, the cost benefit analysis could be conducted to prove that the rainwater harvesting system is a cost-effective technology. Besides that, education and awareness pertaining to rainwater harvesting need to be conducted as well such as campaigns to promote benefit and importance of rainwater harvesting system. Initiatives to incorporate rainwater harvesting system into student education curriculum should be done as well.

Rain water quality studies should be done regularly and continuously to get the long-term quality of harvested rainwater for domestic use of students. The study also indirectly help increase students' awareness of the importance of water management practice in particular rainwater as an alternative to the existing water supply. Rainwater harvesting system is very convenient practiced primarily in addressing the water crisis. Water storage tank is able to accommodate the required moisture content as an alternative source of water as supplies. Table 1 shows several efforts for sustainable harvesting of rainwater need to be conducted.

Table 1: Efforts for sustainable rainwater harvesting

\begin{tabular}{ll}
\hline No. & \multicolumn{1}{c}{ Effort } \\
\hline 1 & $\begin{array}{l}\text { Maintenance and regular cleaning of the roof KUO to ensure } \\
\text { the cleanliness of the water collected before the rain water } \\
\text { treatment process. }\end{array}$ \\
2 & $\begin{array}{l}\text { Conduct regular monitoring on the rainwater harvesting } \\
\text { system that provided the perfect treatment sessions to avoid } \\
\text { disruption of water after treatment. }\end{array}$ \\
& $\begin{array}{l}\text { Ensure the roof is in good condition such as no leakage of } \\
\text { rainwater collected from the roof before the rain water } \\
\text { treatment process. }\end{array}$ \\
\hline
\end{tabular}

In addition, the concept of Triple Helix of government-industry-university relationships together with active participation from community towards sustainable water management in Malaysia need to be up-scaled. The Malaysian Triple Helix Partnership program (My3HP Program) can be proposed by analysing initiatives and guidelines pertaining to the implementation of rainwater harvesting system globally and locally. My3HP program could serve as a starting point to explore systematically responsibilities of different stakeholders for the transition towards sustainable water management in Malaysia.

\section{REFERENCES}

[1] Hashim, H., Hudzori, A., Yusop, Z., Ho, W.S. 2013. Simulation based programming for optimization of large-scale rainwater harvesting system: Malaysia case study. Resources, Conservation and Recycling, 80, 1-9.

[2] Kumar, R., Singh, R.D., Sharma, K.D. 2005. Water resources of India. Current science, 89 (5), 794-811.

[3] Abdulla, F.A., Al-Shareef, A.W. 2009. Roof rainwater harvesting systems for household water supply in Jordan. Desalination, 243 (1-3), 195-207. 
[4] Rahman, S., Khan, M.T.R., Akib, S., Che Din, N., Biswas, S.K., Shirazi, S.M. 2014. Sustainability of Rainwater Harvesting System in terms of Water Quality. The Scientific World Journal, 721357, 10 pages. http://dx.doi.org/10.1155/2014/721357.

[5] Herrmann, T., Schmida, U. 2000. Rainwater utilisation in Germany: efficiency, dimensioning, hydraulic and environmental aspects. Urban Water, 1 (4), 307-316.

[6] Coombes, P.J., Argue, J.R., Kuczera, G. 2000. Figtree Place: a case study in water sensitive urban development (WSUD). Urban Water, 1 (4), 335343.

[7] Ghisi, E., Bressan, D.L., Martini, M. 2007. Rainwater tank capacity and potential for potable water savings by using rainwater in the residential sector of South Eastern Brazil. Building and Environment, 42 (4), 16541666.
[8] Farreny, R., Morales-Pinzón, T., Guisasola, A., Tayà, C., Rieradevall, J., Gabarrell, X. 2011. Roof selection for rainwater harvesting: quantity and quality assessments in Spain. Water Research, 45 (10), 3245-3254.

[9] Despins, C., Farahbakhsh, K., Leidl, C. 2009. Assessment of rainwater quality from rainwater harvesting systems in Ontario, Canada. Journal of Water Supply, 58 (2), 117-134.

[10] Radaideh, J., Al-Zboon, K., Al-Harahsheh, A., Al-Adamat, R. 2009. Quality assessment of harvested rainwater for domestic uses, Jordan. Journal of Earth and Environmental Sciences, 2 (1), 26-31.

[11] Baguma, D., Loiskandl, W., Darnhofer, I., Jung, H., Hauser, M. 2010. Knowledge of measures to safeguard harvested rainwater quality in rural domestic households. Journal of Water and Health, 8 (2), 334-345. 